\title{
CELULARES: A EMERGÊNCIA DE UM NOVO TIPO DE CONTROLE MATERNO
}

\author{
Ana Maria Nicolaci-da-Costa \\ Pontifícia Universidade Católica do Rio de Janeiro
}

RESUMO: Em uma pesquisa exploratória sobre o uso de celulares por jovens das camadas médias cariocas, entre 18 e 25 de idade, foi constatado que eles reclamavam muito que suas mães os controlavam ininterruptamente por meio de seus celulares. Para averiguar mais detalhadamente o que acontece entre mães e filhos dessa faixa etária, foi realizada uma segunda pesquisa. Nesta, foram entrevistadas 20 mães, também pertencentes às camadas médias cariocas, cujos filhos tinham perfil análogo ao dos jovens da primeira pesquisa. Para todas, a principal função dos celulares é abertamente a de controlar os filhos. Elas mostraram, no entanto, saber que há uma diferença entre o controle que vigorava quando eram jovens e aquele ao qual hoje submetem os filhos. Teorias contemporâneas sobre controle e vigilância de fato argumentam que houve uma substituição do controle normativo e coercitivo da modernidade pelo "ter conhecimento" do que se passa, característico da Era da Informação.

PALAVRAS-CHAVE: controle; vigilância; celulares; modernidade; Era da Informação.

\section{CELL PHONES: THE EMERGENCE \\ OF A NEW KIND OF MATERNAL CONTROL}

ABSTRACT: An exploratory research on the use of cell phones by middle-class youngsters, ages 18 to 25 , residing in Rio de Janeiro, revealed that they complained a great deal that their mothers controlled them unrelentingly by means of cell phones. To take a deeper look into what happens between mothers and children in this age group, a second investigation was carried out. Twenty middle-class mothers were interviewed, whose children's profile were analogous to that of the youngsters in the previous research. For all of the mothers, the main benefit of cell phones is to control their children. Nevertheless, they demonstrated to know that there's a difference between the control that they submit their children to from that that prevailed when they themselves were young. Contemporary control and surveillance theories, in fact, argue that the normative and coercive control of modernity has been replaced by "having knowledge" of what goes on, which is characteristic of the Information Era.

KEYWORDS: control; surveillance; cell phones; modernity; Information Era.

A telefonia celular instaurou a era do contato instantâneo independente da distância e das barreiras físicas que separam os interlocutores bem como da mobinidade destes. Esta capacidade de conexão fácil e imediata rapidamente angariou milhões de adeptos ao redor do mundo e, ao fazê-lo, possibilitou a seus usuários um contato constante com suas redes social, familiar e/ ou profissional (Ito \& Okabe, 2003; Kim, 2002; Kopomaa, 2000; Ling, 2004; Mäenpäa, 2001; Nicolaci-da-Costa, 2004a, 2004b).

Entre os usuários que mais se sentiram atraídos pelas possibilidades de contato constante independente de lugar certamente estão os jovens. Na realidade, ao que vários estudos realizados em diferentes contextos culturais indicam (Ito \& Okabe, 2003; Nicolaci-da-Costa, 2004a, 2004b, 2004c, Ling, 2004), a telefonia celular parece ter dado concretude a pelo menos algumas de suas aspirações de autonomia e liberdade. Vejamos.

Diferentemente do que acontecia há algumas décadas, quando havia somente um ou dois telefones fixos "da casa", que eram usados por toda a família, esses jovens passaram a dispor de um telefone particular com "superpoderes". Para começar, dado que o celular é propriedade individual de cada jovem, cada um deles passou a poder armazenar os números dos membros de sua própria rede social na memória do aparelho. A partir desse momento, alguns poucos toques são suficientes para que qualquer membro dessa rede seja instantaneamente contatado a partir de qualquer lugar e praticamente a qualquer hora. Este simples e rápido modo de entrar em contato com amigos, familiares e outros conhecidos, por sua vez, tem várias consequiências importantes.

A primeira delas é a de que, diferentemente do que acontecia antes, quando toda a família tinha acesso a um ou dois telefones fixos, esses contatos passam a poder ocorrer (e geralmente ocorrem) longe dos olhos e ouvidos dos pais. A área de privacidade jovem, por conseguinte, é sensivelmente dilatada em relação aos padrões tradicionais. (Nicolaci-da-Costa, 2004a).

A segunda consequiência do mesmo fácil acesso à rede de conhecidos, amigos e familiares é uma maior sensação de segurança por parte dos jovens usuários da telefonia celular. Isso porque podem pedir ajuda em caso de necessidade 24 horas por dia e essa ajuda pode ser solicitada de modo diferenciado. Pais podem ser chamados para resol- 
ver problemas objetivos como um pneu furado. Enquanto isso, amigos podem ser acionados para fazer companhia, ouvir confidências ou até mesmo dar apoio em horas de crise, como no caso de brigas com namorados ou namoradas (Nicolaci-da-Costa, 2004a, 2004b).

A terceira conseqüência do contato instantâneo independente de lugar é a possibilidade, antes inexistente, de os jovens se programarem ao sabor dos acontecimentos (Almeida \& Tracy, 2003; Ito \& Okabe, 2003, Ling, 2004). Dito de outro modo, com o advento dos celulares, os horários de encontros entre eles se tornaram flexíveis e os locais desses encontros se tornaram cambiáveis na medida em que podem ser marcados e desmarcados ao longo da própria programação. Contanto que estejam "no celular" (ou seja, que carreguem consigo seus aparelhos móveis), o mesmo potencial de contato constante permite a seus pais saberem onde eles estão ao longo do dia e da noite, o que lhes outorga uma autonomia e liberdade de ação sem precedentes se considerados os padrões tradicionais de sua faixa etária e grupo social.

Todos esses resultados e conclusões, bem como a literatura (praticamente toda internacional) que lhes dá subsídios, já foram discutidos por Nicolaci-da-Costa (2004a, 2004b, 2004c) quando da apresentação de uma pesquisa exploratória sobre o uso de celulares realizada com jovens universitários entre 18 e 25 anos de idade pertencentes às camadas médias da zona sul da cidade do Rio de Janeiro. A mesma pesquisa trouxe à tona, porém, um outro resultado, ainda não devidamente explorado, que chamou a atenção por emergir espontaneamente no discurso de vários dos jovens nas entrevistas que com eles foram realizadas para coleta de material. Dele segue-se uma pequena descrição.

A despeito da liberdade, da privacidade e da autonomia que os celulares lhes propiciaram, vários participantes da pesquisa (todos já legalmente adultos) reclamaram muito do controle à distância que suas mães exerciam sobre eles sem que houvesse qualquer pergunta a esse respeito. (Tal como em outras pesquisas - ver Ling, 2004 os pais raramente eram mencionados.) Ao longo das entrevistas, sua reação era por vezes tão forte que freqüentemente revelavam atender qualquer telefonema que recebessem em seus celulares (quase sempre sabem quem está chamando porque usam o identificador de chamadas) à exceção dos telefonemas de suas mães. E isso acontecia principalmente quando estavam em meio à programação da chamada "night". A título de ilustração, alguns desses depoimentos são apresentados abaixo.

Viviane Batista (21 anos de idade) dizia que a mãe a vigiava demais. Para ela, o celular tem uma desvantagem séria: ${ }^{1}$

... minha mãe me acha em todos os lugares, sabe, não tenho mais aquela desculpa de 'ah, não tinha tele- fone...' É, eu não gosto muito disso, dessa marcação cerrada não, sabe. [Por quê?] Ah porque eu gosto muito de liberdade, assim, aí pô, às vezes ela me liga 4h da manhã, ah tá ainda aí?... Ai que saco, sabe, nem atendo.

Essa mesma desvantagem foi levantada por Sandra Romero (18 anos de idade). Durante a entrevista com ela realizada, esta reclamou várias vezes da mãe. Em dado momento, diante de uma dessas reclamações insistentes, foi-lhe perguntado como se sentia com as constantes chamadas da mãe. Sandra retrucou de imediato: "Ah, [nessas situações] eu desejo que eu não tivesse celular". Por quê? Porque se sentia "invadida". Afirmava que avisava aonde ia antes de sair, mas "mesmo assim ela [a mãe] liga. Que horas você vai voltar? Tipo, fica me controlando toda hora, sabe?".

Pela mesma razão, João Martins (18 anos de idade) declarava não atender as chamadas da mãe que ele dizia "dichavar [ignorar]" e Luís Mello (24 anos de idade) revelava desligar o telefone para não ser encontrado por sua mãe e sua avó quando não dava para avisá-las de algum atraso: "eu já desligo porque sei que vão ligar".

Tal percepção de controle, associada ao grande desconhecimento de como e com quais finalidades mulheres brasileiras que têm filhos com perfil análogo ao desses jovens usam seus celulares, deu lugar a uma nova pesquisa exploratória, cujo relato se segue.

\section{Pesquisa}

O objetivo específico desta nova pesquisa era, portanto, o de investigar como mulheres que têm filhos universitários entre 18 e 25 anos de idade fazem uso de seus celulares no que diz respeito aos mesmos. Incluída neste objetivo estava a intenção de verificar se elas de fato usam a comunicação via telefonia celular para vigiá-los e controlá-los à distância. Para que as particularidades deste contato entre mães e filhos pudessem ser apreendidas, faziase necessário, contudo, identificar as características genéricas do uso que elas faziam de seus telefones móveis. Para tanto, dado que se tinha o propósito de estabelecer algumas comparações entre os resultados desta pesquisa e daquela anteriormente realizada com jovens da mesma faixa etária que seus filhos (Nicolaci-da-Costa 2004a, 2004b, 2004c), foi empregada a mesma metodologia utilizada nesta última bem como foram gerados instrumentos análogos de coleta de dados.

\section{Método}

\section{Participantes}

Tendo em vista seu caráter exploratório e a profundidade que um estudo qualitativo quase sempre almeja alcançar, tal como no caso da pesquisa com os jovens foi necessário que a investigação se concentrasse em torno 
de um pequeno grupo de mães que tivessem algumas características básicas em comum (Nicolaci-da-Costa, 2004a, 2004 b, in press). Este grupo deveria também ter um perfil compatível com aquele dos jovens que fizeram parte da primeira pesquisa de modo a possibilitar comparações entre os dois grupos. Por estes motivos, foram estabelecidos os seguintes critérios para o recrutamento das participantes: (a) Para que pudesse emergir uma perspectiva complementar àquela dos jovens da primeira pesquisa, todas deveriam ter filhos com o mesmo perfil e faixa etária destes (ou seja, seus filhos deveriam ser universitários com idades entre 18 e 25 anos). (b) Tal como os jovens na primeira pesquisa, todas as participantes do presente estudo deveriam pertencer às camadas médias da cidade do Rio de Janeiro. (c) Todas deveriam morar com os filhos, na medida em que o que estava sendo investigado era a comunicação cotidiana entre mães e os filhos que ainda estão sob sua guarda. (d) Todas deveriam ter celular próprio há no mínimo um ano, pois alguma experiência é imprescindível para que a comunicação aconteça de forma eficaz e rotineira.

Com base nesses critérios, foram recrutadas vinte participantes a partir de indicações de conhecidos dos pesquisadores. Suas idades variavam entre 41 e 55 anos (uma não quis revelar sua idade exata - dizia ter "40 e tal" -, mas a média de idade das demais ficou em torno de 49 anos). Tinham entre 1 e 3 filhos (totalizando 41 jovens, somente dois dos quais não tinham celulares, um por ser muito jovem e outra por não gostar). Apenas 9 eram casadas (outras 9 eram divorciadas ou separadas e 2 eram viúvas). Seu tempo de uso de celulares variava entre 2 e 10 anos (somente uma entrevistada tinha celular há 2 anos, e pelo menos cinco já possuíam celulares há mais de 8 anos à época da entrevista (a média de tempo de uso ficou em torno de 5 anos e 6 meses). A todas foram atribuídos nomes fictícios para a preservação de seu anonimato.

\section{Coleta de dados}

Os dados foram coletados por meio de entrevistas individuais de, em média, cerca de uma hora de duração. De modo a que se assemelhassem a uma conversa informal e descontraída - o que era de fundamental importância para que as entrevistadas se sentissem à vontade para revelar suas opiniões, pensamentos e sentimentos (Labov, 1972; Nicolaci-da-Costa, 1989, in press) - todas as entrevistas foram realizadas em locais escolhidos pelas próprias participantes.

Inicialmente, eram coletados dados objetivos de cada uma das participantes: sua idade, ocupação, estado civil, número de filhos, idade dos filhos, número de pessoas com quem morava (e quem eram essas pessoas), tempo de uso de um celular próprio e número de filhos que tinham celulares.

A seguir, tinha início a coleta de dados subjetivos. Esta era realizada a partir de um roteiro construído de acordo com as diretrizes propostas por Nicolaci-da-Costa (1989, in press). Este roteiro tinha como base aquele usado nas entrevistas com os jovens, que foi o ponto de partida da presente investigação. Como já foi mencionado, respeitadas as diferenças de faixas etárias, a intenção era a de tornar possíveis comparações entre as respostas dos jovens entrevistados anteriormente e as respostas das mães de jovens de sua faixa etária que estavam participando desta nova pesquisa.

Como pode ser observado abaixo, o roteiro era composto de 40 itens principais a partir dos quais eram formuladas perguntas durante a própria entrevista. Este procedimento objetivava evitar que as perguntas fossem lidas durante a entrevista e, conseqüientemente, soassem artificiais; era importante manter as características de uma conversa natural para que as entrevistadas se sentissem à vontade (Nicolaci-da-Costa, 2004a, in press). Com o mesmo objetivo, procurava-se preservar o fluxo do raciocínio das entrevistadas. Por essa razão, a ordem dos itens podia mudar de uma entrevista para outra (sendo que itens abordados espontaneamente pelas entrevistadas sequer necessitavam ser mencionados pelos entrevistadores). A maior parte desse roteiro era composta de itens/perguntas abertos (que permitem qualquer tipo de resposta). Quando necessários, eram incluídos itens/perguntas fechados (cujas respostas são sim e não), sempre seguidos de perguntas de aprofundamento, como: “por quê?"; “como?”; “onde?”, “dá para explicar melhor?". Os itens/perguntas do roteiro eram agrupados em blocos temáticos, que são apresentados, na íntegra, a seguir.

Uso do celular: quando comprou o primeiro celular (por quê); como usa o celular (recebe mais chamadas, faz mais chamadas; quem liga para a entrevistada; para quem ela liga); qual a maior utilidade do celular para ela; se tem o número do celular das amigas; se elas têm o número da entrevistada; se tem o celular sempre por perto (onde, como); se o celular está sempre ligado (por quê); se usa a agenda do celular (em caso positivo, quem são as pessoas cujos telefones estão armazenados); se tem esses números somente na agenda do celular (em caso negativo, onde mais); se atende qualquer um no celular em qualquer lugar e a qualquer hora (em caso negativo, quem atende, por quê); como se sente se liga para alguém e a ligação não é atendida; como se sente caso isso aconteça com um filho ou filha (por quê); se costuma olhar o visor antes de atender (por quê); se usa toque diferenciado (em caso positivo, para quem e por quê); como se sente com a possibilidade de ser encontrada a qualquer hora (por quê); como se sente com a possibilidade de encontrar as pessoas em geral e os filhos em particular a qualquer hora; se costuma receber ligações de madrugada (em caso positivo, se recebe essas ligações no fixo ou no celular); quem costuma ligar de madrugada (para quê); o que acha dessas ligações); se costuma fazer liga- 
ções de madrugada (para quem, por quê); se recebe ligações a cobrar (de quem, por quê, como se sente a respeito).

Diferenças entre o telefone fixo e o celular: qual telefone a entrevistada usa mais, celular ou fixo (por quê, para quê); qual número costuma dar primeiro, o do celular ou do fixo (por quê); depois que comprou o celular, como ficou o uso do fixo; quando as pessoas ligam para a entrevistada, ligam para qual, celular ou fixo (por quê); quando a entrevistada liga para os outros, liga para qual primeiro, celular ou fixo (por quê, investigar as ligações para os filhos).

Comunicação na família: quem tem celular em sua casa; se compraram ou ganharam; se ganharam, quem deu e por quê; se compraram, por que o fizeram; como é a comunicação entre os membros da família e outras pessoas da casa; quem liga mais para quem (por quê); com que freqüencia se falam durante o dia (enfatizar conversas com os filhos); para que se falam; se a entrevistada, quando liga para o celular de alguém, costuma perguntar onde a pessoa está (por quê; investigar o que acontece quando liga para as pessoas da família, principalmente para os filhos).

Como a entrevistada se relaciona com o seu celular: se costuma emprestar o celular (por quê, para quem); caso o celular de alguém da família quebre, seja roubado ou perdido, se alguém empresta o seu (quem empresta, para quem); se já teve o celular roubado ou perdido (em caso positivo, como foi e como se sentiu); quais as mudanças positivas que o celular gerou na vida da entrevistada (por quê); quais as mudanças negativas que o celular gerou na vida da entrevistada (por quê); se gostaria de voltar à vida sem celular (por quê).

Privacidade e intimidade: o que é privacidade para a entrevistada; se mudou alguma coisa em sua privacidade com o uso do celular (em caso positivo, o quê e por quê); o que é intimidade para a entrevistada; como fica a intimidade com o uso do celular.

\section{Análise dos dados}

Todas as entrevistas foram integralmente transcritas. Em seguida, foram submetidas às técnicas de análise qualitativa de discurso tal como desenvolvidas por Nicolacida-Costa (1989, in press) e utilizadas em várias de suas pesquisas, como, por exemplo, em Nicolaci-da-Costa (2002a). Tal análise é realizada em duas grandes etapas. Na primeira, são feitas comparações inter-participantes. Nesta, são reunidas todas as respostas de todos os participantes a cada um dos itens/perguntas de modo que o pesquisador possa ter uma visão panorâmica dos depoimentos gerados por cada um desses itens/perguntas. As respostas recorrentes detectadas nesta primeira etapa já fazem emergir os primeiros resultados - ou seja, as tendências centrais das respostas dadas pelo grupo como um todo -, embora estes ainda necessitem de aprofundamento. Na segunda etapa - a da análise intra-participantes -, as respostas de cada um dos entrevistados são analisadas como um único conjunto dentro do qual procura-se detectar possíveis conflitos de opiniões, inconsistências entre respostas, sentimentos contraditórios, etc. Tendo por base o insight ganho nesta segunda etapa, retorna-se à primeira e efetua-se uma re-análise das respostas dadas por todos os participantes a cada uma das perguntas. Estas idas e vindas (que podem ser repetidas quantas vezes forem necessárias) possibilitam o conhecimento aprofundado do material coletado e permitem detectar, além de vários não-ditos (pois, muitas vezes, o que não é verbalizado em uma resposta é claramente verbalizado em outra), os pormenores de sentimentos, conflitos internos e porquês que a pesquisa se propõe a identificar.

\section{Resultados}

\section{Uso genérico}

A grande maioria das entrevistadas revelou preferir usar o telefone fixo para seus contatos telefônicos. Ficou claro que, na maior parte das vezes, o uso que essas mulheres faziam de seus celulares era dirigido principalmente aos filhos, chegando, no máximo, a incluir outros membros do círculo familiar e alguns amigos íntimos (com os quais elas entravam em contato via celular esporadicamente em caso de necessidade).

A este uso restrito estava associado um emprego rudimentar dos sofisticados recursos disponíveis mesmo nos modelos mais simples dos telefones celulares. A maioria das entrevistadas declarou saber apenas ligar e desligar, fazer e receber chamadas. Em outras palavras, elas usavam seus celulares como se estivessem usando um telefone fixo que houvesse adquirido mobilidade de longo alcance.

Joana Pinto (aposentada, 53 anos de idade), por exemplo, afirma que, para ela "Basta ligar e desligar. Esse negócio de entrar na Internet, mandar torpedo ... pra mim não precisa....' Tânia de Castro (professora, 53 anos) e Raquel Dias (economista, 46 anos), entre muitas outras, dizem praticamente o mesmo. Tânia afirma que: "Pra mim é receber a chamada e desligar, só, e acabou. É essa a utilidade do celular...". Já Raquel faz a seguinte declaração: "Eu nunca me aprofundo em saber como ele [o celular] realmente funciona. Ele atende às minhas necessidades: ele toca, eu ligo, entendeu? Acabou! Não preciso de mais do que isso".

Poucas são as mães que fazem uso de outros recursos como torpedos ou toques diferenciados. Somente Elisabeth Dantas (comerciante, 40 anos), que é divorciada e atualmente está iniciando uma nova relação amorosa, informou fazer uso de torpedos. Toques diferenciados também são pouco usados, uma vez que as entrevistadas não conseguem reconhecer sua utilidade na medida em que, quando 
há mais de um toque, elas acabam não conseguindo reconhecer o toque do seu próprio celular. Apenas uma das entrevistadas, Regina Ribeiro (fonoaudióloga, 46 anos) revelou gostar de toques diferenciados e de fato usá-los. Diz achar que "são musiquinhas muito bonitas", que ela escolhe "porque cada pessoa tem uma música que parece com ela".

Um dos poucos recursos próprios de um celular do qual muitas mães, mas não todas, aprenderam a fazer uso - geralmente com os filhos - é o da agenda. Ludmila Alves, (professora de história, 43 anos), por exemplo, diz que: "... agora que eu aprendi a colocar os nomes e telefones, tenho usado [a agenda] direto”. Já Lúcia Pinheiro (administradora de imóveis, 51 anos) revela que a agenda é o máximo de sofisticação que seu emprego do celular comporta: "Uso a agenda e falo no telefone, só".

Equais são os telefones que elas colocam nessas agendas? Geralmente os de sua família e amigos mais chegados. São poucas aquelas que, por razões profissionais, armazenam também os telefones de colegas de trabalho. Este é o caso de Renata Loureiro (médica anestesista, 51 anos), que, além dos telefones da família, tem os telefones de vários médicos armazenados na agenda do seu celular.

Outro recurso usado por muitas é o do identificador de chamadas. Quando seu telefone toca, elas olham o nome ou número que aparece no visor para "filtrar" as chamadas, ou seja, escolher quem irão atender (aquelas que não usam agenda são obrigadas a selecionar números e não nomes). Outras nem mesmo deste recurso fazem uso. Atendem qualquer chamada seja porque são poucas as pessoas para as quais dão os números de seus celulares, seja porque não enxergam quando estão sem óculos (o que acontece com freqüência) e não querem correr o risco de não atender os filhos.

A constatação das limitações às quais está sujeito o emprego cotidiano que as mães que participaram da pesquisa fazem de seus aparelhos celulares não deve, no entanto, fazer com que seja subestimada a utilidade que os celulares têm para elas.

\section{Uso em relação aos filhos}

Sem sombra de dúvida, o principal resultado desta pesquisa diz respeito ao uso que as mães entrevistadas fazem de seus celulares em relação a seus filhos.

Sem exceção, todas as mulheres entrevistadas revelaram que compraram seus celulares e os de seus filhos principalmente com a finalidade de manter contato com estes independentemente de onde eles ou elas próprias estejam.

Elizabeth Dantas ("40 anos e tal”, comerciária), por exemplo, diz ter comprado seu celular: “... exatamente pra ter contato com eles [os filhos] fora de casa, essas coisas né?! Filho sai, pra saber onde é que está, que horas que chega, com quem tá...". Todas as outras entrevista- das fazem revelações análogas. Rafaela Carneiro (45 anos, administradora), por exemplo, diz usar o celular para "uma comunicação mais fácil" com as filhas, "meio que para dar uma certa segurança, para saber onde elas estão".

A preocupação que essas mães demonstram ter com a manutenção desse contato constante é tão grande que, quando o celular de um filho fica sem bateria, quebra, é perdido ou roubado, elas imediatamente dão um jeito de resolver o problema. Emprestam sua bateria, seu celular e/ou providenciam a rápida substituição dos telefones dos filhos.

Quando perguntada se alguma vez seu filho tinha ficado sem celular, Sabrina Padrão (41 anos, advogada), por exemplo, declara: "Não. Já ficou sem bateria... ele esquece de dar carga na bateria e, aí, ele pega a minha, porque a gente tem o mesmo modelo... Isso acontece pra burro". Logo em seguida complementa que, caso ele ficasse sem celular, ela lhe emprestaria o dela "porque... ele está circulando mais na rua do que eu: faculdade, curso, estágio. E, como ele é meu filho, eu fico preocupada".

É também por esse motivo que elas dão ampla liberdade para os filhos telefonarem a cobrar a qualquer hora do dia e da noite. Joana Pinto (53 anos, engenheira) declara textualmente que, no que diz respeito aos seus filhos "Onde quer que eles estejam, prefiro que liguem a cobrar do que não ter notícias”. Débora Costa (49 anos, psicóloga), diz o mesmo. Revela pedir aos filhos que liguem a cobrar, mas que não a deixem sem informação.

Quando os filhos não ligam, elas próprias o fazem. Luciana da Silva (55 anos, psicóloga), por exemplo, revela que não liga com muita freqüência, mas, "às vezes, ... [quando ele] está demorando para chegar, não sei onde está, aí eu ligo só pra dar uma checada, uma conferida, se vem jantar, se vai chegar tarde.... Ele não gosta muito não”. Grace Costa (48 anos, comerciante) diz algo semelhante quando afirma que "gosto é de estar a par do que tá acontecendo. Fico muito preocupada se a Sandra costuma chegar em casa às 18 horas e dá 19 e ela não chega. Aí eu ligo pra saber o que aconteceu".

E por que essa manutenção de contato constante com os filhos é importante? Porque - elas admitem explicitamente - esta é a maneira que têm de controlá-los à distância.

Sabrina Padrão (41 anos, advogada) admite abertamente que comprou o celular para seu filho para: "Controlá-lo [rindo bastante]. Controlá-lo não por achar que ele está fazendo alguma coisa errada, mas controlar para saber se ele já chegou em casa... essas coisas assim". Grace Costa (48 anos, comerciante) também é enfática ao declarar que poder encontrar as filhas é sua prioridade. "Poder encontrálas, saber onde estão, se tá tudo bem”. De modo análogo ao de Sabrina, Grace fala abertamente de controle, hesitando, contudo, ao usar essa palavra antes de qualificar a 
que tipo de controle se refere. Diz: "Rola esse... digamos, controle". E, imediatamente, complementa: "Eu sou liberal, não proíbo de nada, elas têm liberdade pra sair, voltar quando quiserem. Mas eu gosto e faço questão de estar informada, ... porque se acontece alguma coisa eu estou mais ciente da situação, entendeu?".

O controle ao qual Sabrina Padrão e Grace Costa fazem referência jocosa ou hesitante antes de qualificá-lo é convenientemente batizado por Márcia Amorim (54 anos, professora secundária) e Rafaela Carneiro (45 anos, administradora) de "controle entre aspas". As "aspas", no entanto, não estão restritas aos depoimentos de Márcia e Rafaela nem tampouco à risada de Sabrina ou à hesitação de Grace. Estão presentes em praticamente todos os depoimentos coletados sob a forma destas e de outras formas de distanciamento do significado tradicional da palavra controle, quando esta é usada para se referir à vigilância que mantêm sobre os filhos. Quem tenta explicitar a diferença entre o significado tradicional (aquele vigente na época em que era jovem) e o atual é a recém-citada Sabrina Padrão. Espontaneamente, ela faz a seguinte reflexão:

... falando do meu filho, não é porque é adolescente [na realidade, o filho de Sabrina tem 19 anos] que vai fazer besteira... Minha geração... talvez até tinha mais isso. O controle era para saber se fumava baseado. ... Mas [agora] se tem algum meio de alguém da sua família, ... saber onde você está não é para controlar sua vida, mas é para ter segurança porque se surgir um perigo, ocorrer um acidente..., alguém pode te socorrer.

Joana Pinto (53 anos, engenheira) também tenta explicitar a diferença entre diferentes tipos de controle. Diz que, para ela, a principal utilidade do celular é a de controlar seus filhos, mas imediatamente qualifica esse controle:

... quando falo de controle, não é um controle rígido. Eu sou assim, sou mãe coruja... eu gosto de ser a galinha, os filhos debaixo da asa. Mas com a liberdade deles. Não sou de ficar perguntando toda hora. Só quero saber o seguinte, vai dormir em casa, tem previsão de chegada?

Renata Loureiro (51 anos, médica anestesista), por sua vez, enfatiza que o celular facilita "estar ciente do que tá acontecendo, nada além disso".

E "estar ciente" do que está acontecendo, poder acompanhar o que os filhos estão fazendo, ter informação a respeito de onde estão, como estão e com quem estão certamente é o que todas as mães entrevistadas parecem desejar. Como afirma Lúcia Pinheiro (51 anos, administradora de imóveis) a principal utilidade do celular é a de manter as pessoas bem informadas. Em suas próprias palavras: "Estamos no século da informação... precisamos estar antenados com o mundo, com as coisas todas que acontecem. Pra mim a utilidade [do celular] é a de poder ser encon- trada e encontrar quem eu precisar". É claro que, também para ela, a prioridade é encontrar os filhos e por eles poder ser encontrada.

São inúmeras as mães que usam a violência que vem caracterizando a vida na cidade do Rio de Janeiro como justificativa de sua vigilância sobre os filhos. Tânia de Castro (53 anos, professora de português), por exemplo, afirma: "A gente tem medo da violência né, de um assalto, uma coisa assim". Elizabeth Dantas ("40 e tal", comerciária) revela que comprou seu primeiro celular "pra saber onde é que [o filho] está, que horas que chega, com quem tá.... Por causa da violência mesmo, só por isso. Exclusivamente por isso". Para dar somente mais um exemplo de muitos outros possíveis, Patrícia Ferrari (53 anos, dona de casa) revela que comprou seu celular e o de suas filhas "Porque eu fico muito preocupada com a violência, com tudo isso... Eu fico com muito medo. E me preocupo sempre, só durmo quando elas chegam em casa".

A violência não é, no entanto, o único perigo que essas mães procuram administrar à distância. Outros explicitamente mencionados incluem o pneu furado, algum malestar, a possibilidade de um acidente, etc. A existência de riscos - reais e imaginários - para a integridade de seus filhos quando estes estão fora de casa é uma preocupação que permeia todas as entrevistas. Por isso mesmo, ter o celular sempre por perto para responder às chamadas dos filhos (muitas deixam o celular ligado à noite mesmo quando estão em casa), poder encontrá-los em meio à sua circulação cotidiana, saber onde estão e com quem estão, saber que estão bem são comportamentos e atitudes vistos por muitas das entrevistadas como "papel de mãe". De fato, somente os filhos (no caso, todos já jovens adultos) parecem ser objeto de sua preocupação (raramente são mencionados outros membros próximos da família, como os maridos, pais e mães das entrevistadas).

\section{Jovens e mães de jovens: confrontando os resultados de pesquisa}

É chegada a hora de confrontar os resultados acima apresentados com os da pesquisa que deu origem ao presente estudo - aquela anteriormente realizada com jovens da faixa etária dos filhos de nossas entrevistadas - para que possam ser interpretados em conjunto.

Na primeira, não custa lembrar, os jovens, em sua maioria, reclamaram muito do controle sobre eles exercido por suas mães via celular. Alegavam que estas os achavam em qualquer lugar, que queriam saber onde estavam e quando iam voltar para casa, que ligavam por conta de qualquer atraso, etc. Como vimos anteriormente, sentiamse controlados e invadidos e, para escapar, muitas vezes deixavam de atender suas chamadas. Já na pesquisa que acaba de ser apresentada, ficou claro que as mães admitem aberta e espontaneamente (novamente sem que houvesse 
nenhuma pergunta a respeito) que compraram seus celulares exatamente para controlar seus filhos.

Estes achados são bastante consistentes e sugerem que os celulares realmente estão sendo utilizados por mães, pelo menos por mães que têm perfil análogo ao das nossas entrevistadas, para exercerem sobre seus filhos algum tipo de controle (mesmo quando estes já são adultos). E este controle é aquele que, como vimos acima, elas colocam entre aspas ou do qual se distanciam de outras formas discursivas. Resta, agora, tentarmos compreender que tipo de controle é esse.

\section{Discussão: o controle na Era da Informação}

Ainda não estamos tão distantes da sociedade disciplinar a ponto de o uso constante da palavra controle, feito tanto pelos jovens quanto pelas mães entrevistadas, não nos remeter ao controle normativo e coercitivo analisado por Foucault (1975). A palavra controle ainda quase imediatamente nos traz à mente a imagem que Foucault elegeu como seu ícone. Esta imagem, que suas análises do controle no período moderno tornaram bastante conhecida, é a do Panóptico, a estrutura carcerária cujas celas de paredes transparentes dispostas em círculo permitiam total visibilidade dos prisioneiros dia e noite a partir de uma única torre central. Esta associação é ainda tão forte que alguns autores, a exemplo de Rheingold (2003), interpretam a vigilância contemporânea, principalmente aquela levada a cabo pelos novos meios de comunicação digital, como uma ampliação dessa estrutura que permite que todos sejam sempre observados por todos.

Há, no entanto, diversos outros analistas da contemporaneidade que discordam do poder explicativo do Panóptico nos dias de hoje e - tal como as mães entrevistadas fazem ao colocar o controle que exercem entre aspas - diferenciam o controle exercido nos dias de hoje do controle disciplinar exercido durante a Modernidade.

Um desses autores é Deleuze (1990). Tentando dar continuidade ao raciocínio de Foucault, Deleuze diz que, após a II Guerra Mundial, os ambientes de "confinamento" e as instituições da sociedade disciplinar-família, escola, fábrica, etc. - entraram em franco declínio. Como decorrência da queda dos muros institucionais e da crescente mobilidade de tudo e de todos, as sociedades disciplinares transformaram-se em sociedades de controle. Nessas, um tipo de controle fluido substitui as antigas disciplinas que operavam durante a vigência do sistema de confinamento (Deleuze, 1990; Hardt, 2000). ${ }^{2}$

Já outros analistas, embora certamente não discordando desse processo de fluidificação, enfatizam diferentes aspectos dos novos tipos de vigilância e controle. Na realidade, a tentativa de compreender o que significam vigilância e controle nos dias de hoje (geralmente realizada a partir de uma perspectiva macro-social) é tão complexa e envolve tantas variáveis que dá lugar a inúmeras abordagens que enfatizam um ou outro de seus vários aspectos. Até mesmo os nomes de batismo dados à sociedade contemporânea variam conforme o ponto de vista adotado. Entre esses nomes de batismo, temos o da já mencionada sociedade de controle, além de outros como: sociedade da informação (Castells, 2000), sociedade da vigilância (Lyon, 2001), sociedade de risco (Beck, 1995).

O propósito da presente exposição não é, porém, o de empreender uma (certamente extensa) revisão das teorias que procuram dar conta da dinâmica social no mundo contemporâneo e, sim, interpretar resultados de pesquisa. Assim, serão eleitos alguns aspectos de uma corrente teórica que, além de incorporar as diversas dimensões aludidas nas diferentes nomenclaturas citadas acima (controle, informação, vigilância e risco), permite a construção de uma ponte entre as análises macro-sociais realizadas por vários de seus autores e a realidade micro-social na qual se inserem os presentes resultados e os de outras pesquisas análogas (Fotel \& Thomsen, 2004). Esta abordagem é dos chamados "estudos da vigilância", entre os quais podem ser inseridos os trabalhos de Lyon (2001) sobre a sociedade da vigilância e de Lianos (2003) sobre o controle social após Foucault.

Comecemos por Lianos (2003) para que se torne mais evidente a ligação com o raciocínio de Foucault exposto anteriormente. Lianos afirma que, após Foucault, o estudo do controle social não progrediu muito. Em grande parte, segundo ele, isso acontece porque há uma grande dificuldade de se registrar que o modelo proposto por Foucault durante a modernidade não pode contemplar a emergência do sujeito pós-industrial contemporâneo e é "freqüientemente mal interpretado e projetado no presente sem quaisquer nuanças"' (Lianos, 2003, p.412, minha tradução). Para Lianos, o controle disciplinar e moral é coisa do passado; precisamos aprender a pensar o controle sem associá-lo à disciplina e à tentativa de inculcar valores. Esta é uma das principais diferenças que Lianos percebe entre o controle estudado por Foucault e aquele levado a cabo hoje. Outra importante diferença é a de que o controle que resulta da vigilância contemporânea é sempre justificado e traz consigo benefícios difíceis de recusar por quem dele é objeto (como, por exemplo, a facilidade de fazer compras com um cartão de crédito mesmo sabendo que os dados fornecidos poderão ser utilizados para outras finalidades). Ambos esses aspectos que diferenciam o controle disciplinar das práticas de controle contemporâneas estão contidas na seguinte citação:

... a maior parte do que pode ser chamado de controle [nos dias de hoje] não tem seu foco dirigido para práticas de confinamento nem tampouco para a opressão de comportamentos ou de idéias. Concentra-se na organização e na contextualização daquilo que é muitas vezes intencionado ou mesmo desejado por um sujeito soberano (Lianos, 2003, p. 416, minha tradução). 
Lianos argumenta, ainda, que passamos a viver numa sociedade de estranhos que não têm regras claras a seguir ou instituições para conter seus desejos. Nesta sociedade de estranhos, como não poderia deixar de acontecer, predomina a suspeita. É o que ele chama de "cultura do perigo" (culture of dangerisation). Este argumento é, no entanto, mais detidamente analisado sob a rubrica de "risco" por Lyon (2001) e por vários autores de outras correntes teóricas, a exemplo de Beck (1975) e Bauman (1997, 2001, 2005), cujas contribuições já foram mais minuciosamente analisadas anteriormente (Leitão \& Nicolaci-daCosta, 2004).

Lyon (2001) discorre de forma semelhante àquela de Lianos sobre as diferenças entre o controle disciplinar e o controle contemporâneo e também sobre a inadequação do modelo disciplinar de Foucault para dar conta da vigilância e do controle levados a cabo na atualidade. Dá, no entanto, maior ênfase às novas tecnologias de comunicação e informação. Chega mesmo a afirmar que "todas as sociedades que dependem das tecnologias de comunicação e informação para finalidades administrativas e processos de controle são sociedades de vigilância" (Lyon, 2001, p. 1 , minha tradução). De seu ponto de vista, as agências e organizações que monitoram nossas atividades diárias estão tentando administrar riscos, ou seja, reduzir incertezas e controlar resultados.

Para uma análise da vigilância empreendida nessas sociedades por todos os tipos de corporações, Lyon propõe o exame de quatro elementos chave: coordenação, privacidade, poder e risco. Coordenação se refere aos modos pelos quais as relações sociais estão adquirindo novas formas com o crescimento das novas tecnologias de informação e telecomunicação (uma corporação tem cada vez mais ciência, por exemplo, das atividades diárias de seus empregados e consumidores). A privacidade se contrapõe à vigilância e tem suas fronteiras pouco nítidas nos dias de hoje (a fluidez da comunicação é um dos elementos que contribui para essa ausência de nitidez). Não há mais um poder central como aquele simbolizado pela torre de vigilância no Panóptico; "o poder parece fluir por uma variedade de canais" e, na maior parte do tempo, a grande maioria das pessoas aceita a vigilância de bom grado por conta dos benefícios que dela deriva. A vigilância é o meio através do qual conhecimento é produzido de modo a administrar populações com relação ao último dos quatro temas listados acima: o risco. Em busca de segurança, todas as instituições em praticamente todos os setores procuram minimizar o risco coletando informações a respeito de tantos fatores quanto for possível.

Por fim, Lyon afirma que: "sociedades de vigilância existem onde quer que a vigilância deixe de ser uma característica discreta de relações institucionais e se torne um procedimento de rotina difundido nas populações" (Lyon,
2001, p. 38, minha tradução). Ainda segundo Lyon, nesse tipo de sociedade, as pessoas tendem a ter uma consciência cada vez mais aguda de riscos (de todos os tipos).

Gostaria, agora, de argumentar que os quatro elementos chave discutidos por Lyon (2001) associados a outros insights, tanto seus quanto de Lianos (2003), podem ser transportados do plano macro para o micro-social e usados para interpretar nossos achados. Vejamos.

Por vivermos em uma sociedade de vigilância, todos acabamos por introjetar as principais características dessa sociedade. Isso certamente parece ter acontecido com os jovens e as mães que participaram de nossos estudos.

No que diz respeito à coordenação, como foi dito na introdução, os celulares propiciaram aos jovens a dilatação de sua área de privacidade (que em grande parte se tornou móvel) e também a ampliação de sua autonomia. As relações entre mães e filhos também foram alteradas. $\mathrm{O}$ contato face a face entre mães e seus filhos jovensadultos diminuiu na medida em que estes, para coordenarem suas atividades, trocaram a base do telefone fixo da casa pela base móvel dos telefones celulares. Isso, no entanto, não impediu que jovens e suas mães continuassem constantemente em contato, agora via celulares. Esse contato constante com suas mães foi um compromisso tacitamente aceito pelos próprios jovens (aqui está a aquiescência voluntária aos procedimentos de vigilância) em troca de receberem um celular para uso.

O poder acha-se diluído na sociedade como um todo e as mães perderam boa parte do poder que antes tinham. Não deixaram, no entanto, de ter algum poder sobre os filhos jovens-adultos que com elas moram. Antes, mães disciplinavam, ditavam normas, horários, condutas, etc. Agora, elas perderam boa parte deste poder (pelo menos no que diz respeito à faixa etária estudada), mas têm o poder de exigir que seus filhos as deixem informadas - via celulares - a respeito de onde estão, de com quem estão, da hora em que vão chegar, etc. E, quando eles não fornecem essa informação voluntariamente, elas se sentem com o direito de buscá-la e o fazem sem qualquer restrição. Este é o controle que podem exercer e de fato exercem sobre os filhos.

A vigilância constante que as mães exercem sobre os seus filhos resulta no e se confunde com o "controle entre aspas" ao qual elas se referem. Esta vigilância é justificada e acirrada pela crescente consciência de riscos de todos os tipos (reais e imaginários) aos quais os jovens se encontram expostos (principalmente numa cidade especialmente violenta como a do Rio de Janeiro deste início de milênio). Essa mesma vigilância é sentida pelos filhos como o que é: controle. Isso porque interfere em sua autonomia e invade sua privacidade (ambas, como vimos antes, dilatadas pela própria tecnologia que as mães usam para monitorá-los). 
Quase sempre sem que disso tivessem consciência, este foi o preço que os jovens estudados, direta e indiretamente, nas duas pesquisas aqui reportadas aceitaram pagar para que pudessem ter seus celulares presenteados pelos pais e, no mais das vezes, também suas altas contas telefônicas pagas por estes. Em seu caso, e muito provavelmente também no de outros tantos jovens, serem objeto do novo tipo de controle discutido acima é a contrapartida para que possam desfrutar de uma liberdade e de uma autonomia precocemente ampliadas em relação aos padrões tradicionais antes em vigor para sua faixa etária e posição social. Na ausência de uma real emancipação de seus pais, esta solução, ideal para suas mães, por mais que por eles seja sentida como um incômodo ou uma invasão ainda lhes é bastante atraente.

\section{Notas}

1 Todas as falas dos participantes da pesquisa foram transcritas com suas características originais, inclusive os erros tão freqüentes no discurso oral.

2 Embora escrevendo em 1990, Deleuze chega a prever a criação de uma espécie de "coleira digital" que forneceria a posição de qualquer elemento (um animal numa floresta ou um ser humano numa corporação) dentro de um ambiente aberto a qualquer momento. A imagem da "coleira digital" é usada por alguns autores contemporâneos no que diz respeito ao controle exercido, via celular, por mães sobre filhos pequenos e adolescentes (Ling, 2004).

\section{Referências}

Almeida, M. I. M. \& Tracy, K. M. A. (2003). Noites nômades: espaço e subjetividade nas culturas contemporâneas. Rio de Janeiro: Rocco.

Bauman, Z. (1997). O mal-estar da pós-modernidade. Rio de Janeiro: Jorge Zahar.

Bauman,Z. (2001). Modernidade líquida. Rio de Janeiro: Jorge Zahar. Bauman, Z. (2005). Vidas desperdiçadas. Rio de Janeiro: Jorge Zahar. Beck, U. (1995). Autodissolução e auto-risco da sociedade industrial: o que isso significa? In U. Beck, A. Giddens, \& S. Lash (Eds.), Modernização reflexiva: política, tradição e estética na ordem social moderna (pp. 207-218). São Paulo: Editora da Universidade Estadual Paulista.

Castells, M. (2000). A sociedade em Rede. São Paulo: Paz e Terra.

Deleuze, G. (1990). Post-scriptum sur les sociétés de contrôle. L'autre journal, 1.

Fotel, T. \& Thomsen, T. U. (2004). The surveillance of children's mobility. Surveillance \& Society, 1(4), 535-554.

Foucault, M. (1975). Surveiller et punir: Naissance de la prison. Paris: Gallimard.

Hardt, M. (2000). A sociedade mundial de controle. In E. Alliez (Ed.), Gilles Deleuze: uma vida filosófica. São Paulo: Editora 34.

Ito, M. \& Okabe, D. (2003). Mobile phones, Japanese youth and the re-placement of social contact. Retrieved on 11/12/2003 from http://www.itofisher.com/PEOPLE/mito/mobileyouth.pdf

Kim, S. D. (2002). Korea: personal meanings. In J. E. Katz \& M. Aakhus (Eds.), Perpetual contact: Mobile communication, private talk, public performance (pp. 63-79). Cambridge: Cambridge University Press.
Kopomaa, T. (2000). Speaking mobile: the city in your pocket. Helsinki: Gaudeamus.

Labov, W. (1972). The logic of nonstandard English. In W. Labov (Ed.), Language in the inner city (pp. 201-240). Philadelphia: University of Pennsylvania Press.

Leitão, C. \& Nicolaci-da-Costa, A. M. (2004). A psicologia no contexto mundial. Estudos de Psicologia (Natal), 8(3), 421-430.

Lianos, M. (2003). Social control after Foucault. Surveillance \& Society, 1(3), 412-430.

Ling, R. (2004). The mobile connection: The cell phone's impact on society. San Francisco: Morgan Kaufmann.

Lyon, D. (2001). Surveillance society: Monitoring everyday life. Buckingham: Open University press.

Mäenpäa, P. (2001). Mobile communication as a way of urban life. In A. Warde \& J. Gronow (Eds.), Ordinary consumption (pp. 107-123). Londres: Routledge.

Nicolaci-da-Costa, A. M. (1989). Questões metodológicas sobre a análise de discurso. Psicologia: Reflexão e Crítica, 4(1/2), 103108.

Nicolaci-da-Costa, A. M. (2004a). Impactos psicológicos do uso de celulares: uma pesquisa exploratória com jovens brasileiros. Psicologia: Teoria e Pesquisa, 20(2), 165-174.

Nicolaci-da-Costa, A. M. (2004b). A passagem interna da modernidade para a pós-modernidade. Psicologia: Ciência e Profissão, 24(1), 82-93.

Nicolaci-da-Costa, A. M. (2004c). Tudo o que tenho de fixo na vida é meu celular: os celulares como âncoras da identidade dos jovens nômades urbanos. Trabalho apresentado no VIII Congresso LusoAfro-Brasileiro de Ciências Sociais, Coimbra, Portugal. Disponível em http://www.ces.uc.pt/lab2004/inscricao/pdfs/painel24/ AnaMAriaNicolacidacosta.pdf.

Nicolaci-da-Costa, A. M. (in press). O campo da pesquisa qualitativa e o Método de Explicitação do Discurso Subjacente (MEDS). Psicologia: Reflexão e Crítica.

Rheingold, H. (2003). Smart mobs: the next social revolution. Cambridge, Mass.: Perseus Books.

Ana Maria Nicolaci-da-Costa. Psicóloga, Mestre em Psicologia pela New School for Social Research (NY).

Endereço para correspondência: Departamento de Psicologia, Rua Marquês de São Vicente, 225, Gávea, 22543 900, Rio de Janeiro, RJ. Fone: (21) 35271183 , 3527 1185; Fax: (21)35271187. anicol@psi.puc-rio.br

Agradecimento: Ao apoio dado pelo CNPq sob a forma de bolsa de produtividade em pesquisa, auxílio a projetos individuais de pesquisa e bolsas de Iniciação Científica.

\section{Celulares: a emergência de um novo tipo de controle materno}

Ana Maria Nicolaci-da-Costa

Recebido: 17/07/2006

$1^{a}$ revisão: 11/08/2006

Aceite final: 15/08/2006 